\title{
剤形開発におけるトレードオフ（overview）
}

\author{
内田享弘
}

\section{Trade-offs in the Development of Various Dosage Form (Overview)}

\author{
Takahiro Uchida \\ Faculty of Pharmaceutical Sciences, Mukogawa Women's Univeresity; \\ 11-68 Koshien 9-Bancho, Nishinomiya, Hyogo 663-8179, Japan.
}

(Received September 11, 2014)

\begin{abstract}
In this symposium we focused on trade-offs which might occur in the process of development of many types of formulation and corresponding dissolution methods. Firstly, we focused on a solubility-permeability trade-off in the case of micelle with surfactant or molecular complex with CyD. The micelle would be successful in increasing drug solubility, however it rather decreased permeability of model drug progesterone (Biopharmaceutics Classfication System (BCS) Class II) as an overall flux. Secondly in order to reduce bitterness of branched chain amino acid (BCAA), increasing particle sizes of each amino acid crystals involved in formulation was effective since the release rate of amino acid was restricted efficiently. Thirdly, in the case of injection of paclitaxel (BCS Class II) formulation, the drug was adsorbed to albumin. Thereby the risk of allergy was dramatically decreased compared to the case when non-ionic surfactant was used as an additive. Fourth, anticancer drug was incorporated into the internal (core) phase of an orally disintegrating tablet (ODT), this is also merit to avoid exposure of the drug to a nursing person or individual working person in manufacturing process. Fifth, the convenient syringe type kit pharmaceutical preparation for administration of total parenteral nutrition (TPN) to avoid incompatibility and its risk management effect was briefly discussed. Finally, the risk of an additive such as alcohol for a preterm infant was described.
\end{abstract}

Key words_— solubility-permeability; orally disintegrating tablet; anticancer drug; total parenteral nutrition; branchedchain amino acid

\section{はじめに}

経済活動における古典的なトレードオフは時間, 資金，品質のトリオである，トレードオフ（Tradeoffs）とは，「一方を追及すれば他方を犠牲にせざ るを得ないという状態・関係のこと」であり，英和 辞書によれば, a balance achieved between two desirable but imcompatible features: a compromise と記載されている，すなわち同時に追及すれば相容 れなくなる 2 つの特徵のどちらを優先させるか. 妥 協としての相殺取引，いわば交換条件であると記載 されている.

医薬品開発においてもこのようなトレードオフは 存在するが，イノベーションを利用することでト

武庫川女子大学薬学部（干663-8179 兵庫県西宮市甲子 園九番町 11-68)

e-mail: takahiro@mukogawa-u.ac.jp

本総説は, 日本薬学会第 134 年会シンポジウム S01 で 発表した内容を中心に記述したものである.
レードオフを克服し価值を高めた製剤が開発され， その結果効果的な薬物治療の実践と医療安全への貢 献ができている事例がある。一般に患者志向のため の徐放化や苦味マスキングを目的として，単純に経 口製剤からの放出速度を過度に抑制してしまうとバ イオアベイラビリティ（bioavailability; BA）が低 下するリスクが乗じる．このトレードオフを解決す る画期的な製剂工夫として，苦味マスキングのため に放出制御技術を施した造粒粒子を含んだ口腔内崩 壊錠（orally disintegrating tablet; OD 錠）を開発す ることで，BA 低下もなく，なおかつ良好な苦味マ スキングを達成している。 ${ }^{1-3)}$ すなわち剤形でのイ ノベーション導入によりトレードオフを解決したの である.

本シンポジウムでは，薬剤あるいは製剤自身の有 効性担保と患者の利便性を同時に達成できる製剤技 術や工夫に着目する。すすおち患者視点からの望ま しい剤形のあり方とその製剂開発時に生じるトレー 
ドオフに焦点を当てる，また，有効性のみならず， 患者への安全確保という点でもトレードオフは存在 するが，この医療安全という視点も重要である.

本稿において筆者は，シンポジウム全体の overview を目的として，(1)医薬品の溶解性，膜透過性 を指標として BA が担保できる剤形，(2)抗がん剂成 分を内包する有核型口腔内崩壊錠で，抗がん剂成分 の飛散防止と速やかな崩壊性を両立した製剂例, (3)パクリタキセル [Biopharmaceutics Classfication System（BCS） クラス II] を人血清アルブミンに 結合させた凍結乾燥製剂，(4)肝不全用経口栄養剂配 合散に含まれる苦味アミノ酸の主成分であるイソロ イシン, ロイシン, バリンの結晶の粒子径を大きく することで, 溶出速度を低下させ苦味軽減を達成し た製剤，(5) K（カリウム）の注射剤のワンショット 静注ができないように工夫されたキット製剤，(6)新 生児や小児用の製剂について, 薬剂を溶解するため の可溶化剂の安全性についてもトレードオフという 観点から情報提供し, 各シンポジストからの詳細な データ紹介につなげたい.

1. 医薬品の溶解性, 膜透過性を指標とした BA が担保できる剤形

医薬品開発の流れを Fig. 1 に示す.プレフォー ミュレーションについては, 探索研究や非臨床試験 実施の初期段階でも行い，さらに人での臨床試験で もプレフォーミュレーションを行う。このとき重要 な因子が薬剤の溶解度・膜透過性である。年プレ フォーミュレーション I は主に可溶化の検討を行い,

II では製剤化の検討を行う.

いわゆる BCS 分類のクラス II に分類されている 薬剂は一般に溶解度は低く, しかし膜透過性は高い とされる薬剤群である。 Kawabata らは，そのよう なクラス II 群の薬剤の製剤化の方法として，1）結 晶修飾（準安定形，塩形成，共結晶の形成），2）界 面活剂添加による即放出型の経口製剂化，3）マイ クロ粒子化，ナノ粒子化による微粒子化，4）非晶 質化，5）シクロデキストリン包接体形成，6）自己 乳化型システム, Liquid 充填によるカプセル剂に 代表される Lipid formulation，7）pH 調整剤含有 固体分散体に代表される固形製剂中の $\mathrm{pH}$ 調整など の手法を挙げている. 5$)$

しかしながら例えば界面活性剤を添加して薬物の 溶解度を改善することで BA を上昇させるアプロー

チを考えた場合に，単純にミセル形成により薬剤の 溶解度が上昇しその結果， BA が大きく上昇するこ ととならない. クラス II のプロゲステロンを基質 して考える場合， sodium lauryl sulfate（SLS）の 添加濃度を上げていくと臨界ミセル濃度（critical micelle concentration; CMC) である $0.9 \mathrm{~mm}$ 以上の 濃度でミセル形成によりプロゲステロンの溶解度が 大きく上昇することが報告されている。 ${ }^{6)}$ 文献中, sodium lauryl sulfate や sodium taurocholate などの 界面活性剂を可溶化剂として利用した場合に CMC 以上でプロゲステロンの溶解性は増大するが，非擋 汼層を介した薬物の透過性（permeability）は CMC 以上では逆に大きく低下する． Figure 2 に示 したように，CMC 以下では，消化管腔内はバルク 層とそれに続く非擋汼層からなり，薬物の膜透過は 非擋汼層の透過と膜透過がバリアとなっている (Fig. 2 の上半分). CMC 以上では，ミセル形成の ため非摚汼層が小さくなる効果がある反面，ミセル 中の薬物の存在比率が大きくなるため, 遊離形薬物 濃度が低下してしまう（Fig. 2 の下半分）。した がって CMC 付近ではプロゲステロンの膜透過性 (permeability) は最大となるが，CMC 以上ではプ ロゲステロンの膜透過性はむしろ低下すると報告さ れている. ${ }^{6}$

上記界面活性剂と同様に, シクロデキストリンが 添加された場合も CMC 以上の界面活性濃度添加に より薬物膜透過性は逆に低下する。 このようにミセ ル形成や包接化合物形成 ${ }^{6-8)}$ による溶解性の上昇が 薬物膜透過性の低下をまねくというトレードオフが 提唱されている。一方，非晶化（Amorphization） は，溶解性の上昇を達成するが，薬物の膜透過性は 低下させない。この点で上記トレードオフを生じな いことが報告されている.7)

以上のように，製剤的工夫による溶解性向上と膜 透過性の維持の 2 つを両立させることが望まれる.

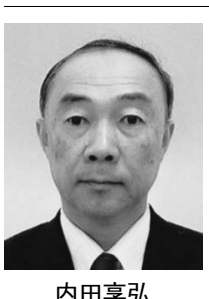

内田享弘
武庫川女子大学薬学部臨床製剂学教室 教授, 研究科薬学専攻長. 昭和 58 年 3 月九州大学薬学部卒業, 同 63 年薬剤学 教室助手, 平成 4 年米国カンサス大学 留学, 病院研修後, 平成 8 年 4 月武庫 川女子大学薬学部臨床薬学教室助教 授, 平成 14 年教授, 平成 9 年日本薬剂 学会旭化成製剤学奨励賞受賞. 

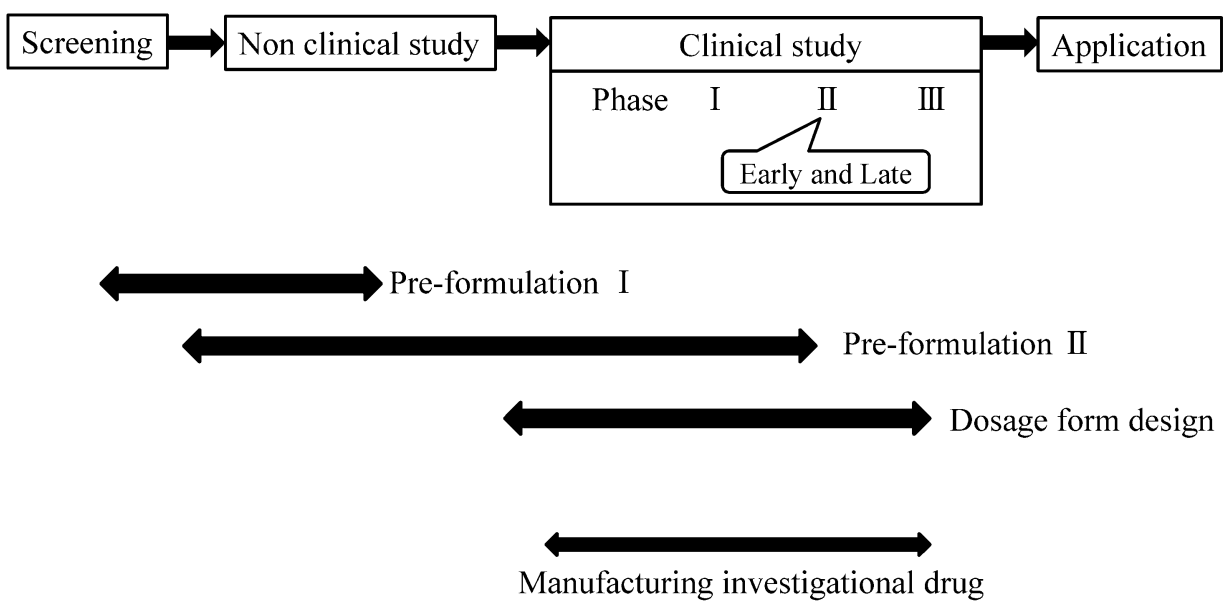

Production

Fig. 1. Drug Development, Dosage Form Design and Manufacturing

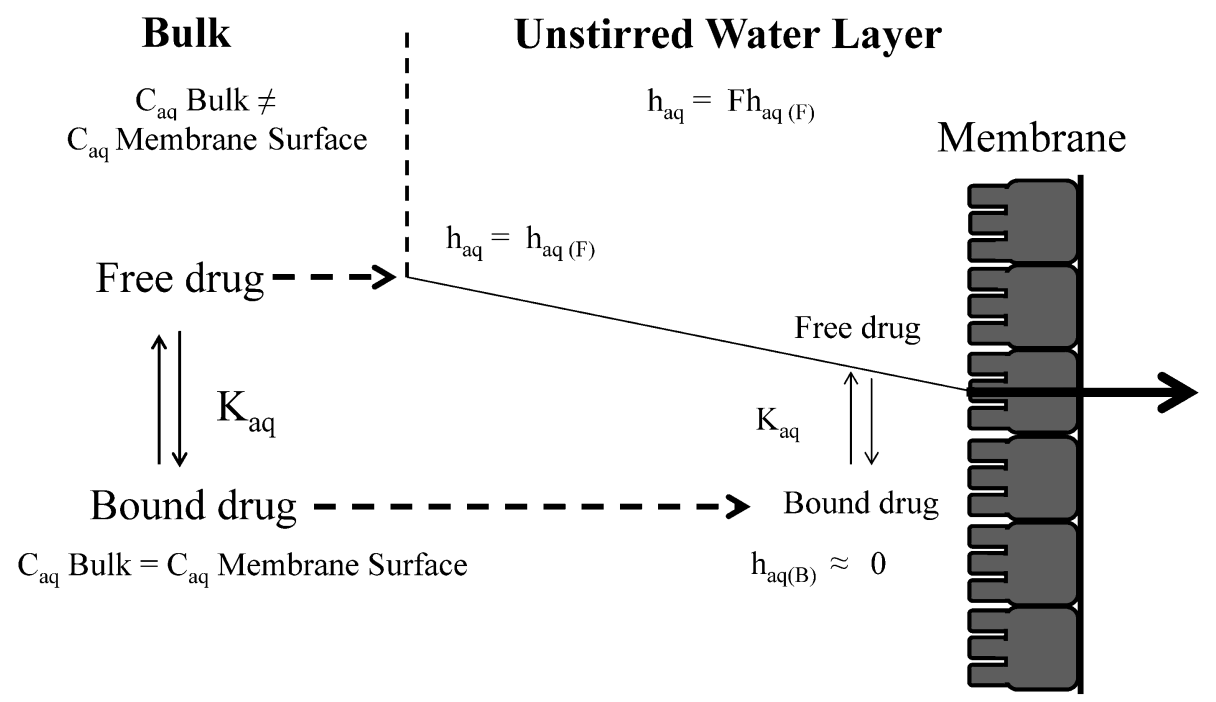

Fig. 2. Solubility-Permeability Trade-off in the Case of Micelle

\section{2. 抗がん剂成分を内包する有核型口腔内崩壊錠} 一抗がん阂の飛散防止と速やかな崩壊性を両立させ た事例

水分摂取が制限されている患者や嚥下困難の患者 では，口腔内で速やかに崩壊する OD 錠が適して いる. ${ }^{1)}$ 抗がん剤においても嚥下能力の低下してい る患者や，唾液分泌が少ない高齢者にとって OD 錠は利点があると考える. ${ }^{9)}$ 抗がん剤を含む OD 錠 の開発や利用を考える場合，患者や介護者からみる と直接 OD 錠にふれて口腔内に含むまでの間の曝 露，医療従事者からも調剂時に一包化する場合の曝 露の問題が考えられる. 製剂としての特性である口 腔内での速やかな崩壊特性を持たせることと，少量
の水分で OD 錠が崩壊して患者自身の指先や介護 者の指先に曝露する危険性は 1 つのトレードオフと 言える.したがって，薬物による污染防止と速やか な崩壊性を兼ね備えた製剤設計が求められる。また 製剂化のラインにおいても作業曝露の危険性を考慮 すべきである.

ティーエスワン（テガフール・ギメラシル・オテ ラシルカリウム）は，通常錠に加えて，OD 錠が開 発・市販されている.

ティーエスワン OD 錠は， 2 重構造杵と杵位置制 御により，有効成分を含有する内核を外殼により確 実に内包し，かつ外殼の厚みを薄くすることで錠剤 の小型化，速やかな崩壊を達成している．従来の有 
External phase: active pharmaceutical ingredients are not contained

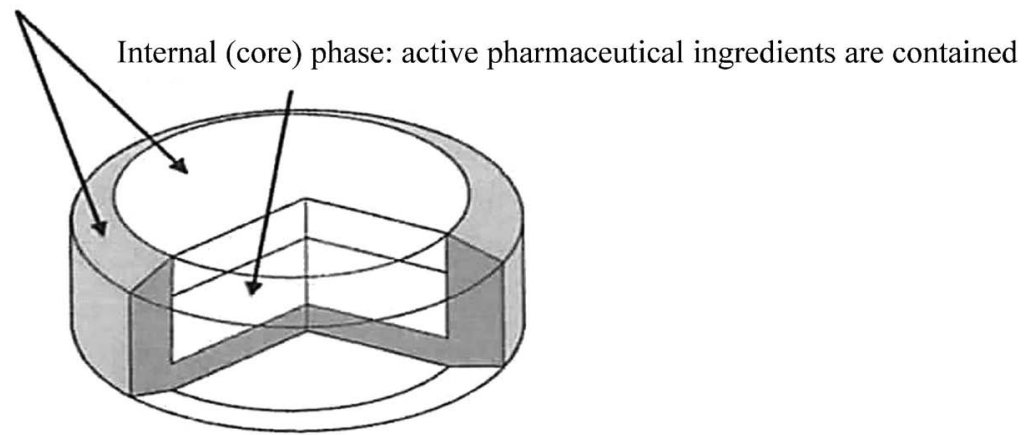

Fig. 3. Structure of ODT Containing Anticancer Drug: The Case of TS-1 Combination OD Tablet T20, T25

核打錠機を用いた打錠では，通常錠剂サイズが大き くなり，崩壊が遅くなる，加えて内核を強固にする 必要があるため速やかな崩壊は通常は不利であると されていた。本 OD 錠はこのような製剤上の高度 の工夫（すなわちイノベーションといっても過言で ないと思う）が導入された凨形である（Fig. 3).

取り扱いにおいても，錠剤の小型化に伴い十分強 度を有しており，しかも内核にのみ抗がん剂成分を 含むので，錠剤を粉砕. 分割をしない限り，その成 分は曝露されないと考えられる，口腔内崩壊錠試験 器を用いた評価においても, 崩壊時間は 20 数秒で あり速やかな崩壊が担保されている.

以上より，ティーエスワン配合 OD 錠は，患者 に服用し易い，水なしで服用できるという OD 錠 全般の利点だけなく, 医療従事者・介護者のみなら ず，工場の生産ラインでの作業時の曝露防止という リスクも解決したトレードオフ解決の事例と考える.

\section{3. パクリタキセル（BCS クラス II）を人血清} アルブミンに結合させた凍結乾燥製剂

従来のパクリタキセル製剤は．溶剤としてポリオ キシエチレンヒマシ油及びエタノールを使用してい た。注射剤一アブラキサン点滴注射用 $100 \mathrm{mg}$ 一は パクリタキセル（BCS クラス II）を人血清アルブ ミンに結合させた凍結乾燥製剤である。本製剤では 生理食塩水で䋰濁し投与することが可能となり, 過 敏症予防のためのステロイド剂や抗ヒスタミン剂の 前投与が可能になる等の利便性が得られ, さらに有 効性の向上も確認された.

ヒト臍帯静脈内皮細胞 (human umbilical vein endothelical cell; HUVEC) に結合するパクリタキセ ル量の検討（in vitro）においては，HUVECを 96 ウェルプレート上で培養後, 蛍光標識したパクリタ キセルで製剤化したアブラキサン又は他のパクリタ キセル製剤を添加し， $37^{\circ} \mathrm{C}$ で 1 時間反応させた 後, 細胞への結合量を蛍光值として測定した結果, アブラキサン群では HUVEC に結合するパクリタ キセルの結合量が多い $(p<0.0001$, 分散分析 $)$ こ とが確認されている. ${ }^{10)}$

\section{4. 肝不全用経ロ栄養剤配合散アミノレバン®}

\section{EN の例}

本製剤は，苦味アミノ酸の主成分であるイソロイ シン, ロイシン, バリンの結晶の粒子径を大きく改 良することで, アミノ酸からの溶出速度を低下させ 苦味軽減を達成している. ${ }^{11)}$ 通常はアミノ酸粒子径 が大きくなるとざらつき感が出て服用し難いと予想 されるが，本製剤水懸濁時は多成分性でコロイド分 散系を形成するため, 水不溶性のアミノ酸の結晶に より舌にざらつき感を呈することもないと考えられ る.

Branched-chain amino acid (BCAA) の粒子径の 異なる 2 つ製剤を電磁式ミクロ型ふるい振とう器 を用いて比較した結果を Fig. 4 に示した。 BCAA の粒子径が小さいアミノレバン ${ }_{\mathbb{E}} \mathrm{EN}$ の旧製剤中の BCAA の粒子径は約 40-90 $\mu \mathrm{m}$ であるのに対して, 改良製剤は粒子径が 180-250 $\mu \mathrm{m}$ と大きいことが確 認された. ${ }^{11)}$

粒子径の異なる BCAA からなるアミノレバン®

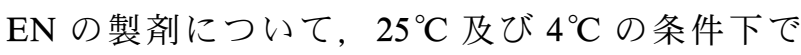
BCAA の経時的な溶出率を評価したところ, Figs.

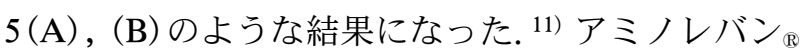



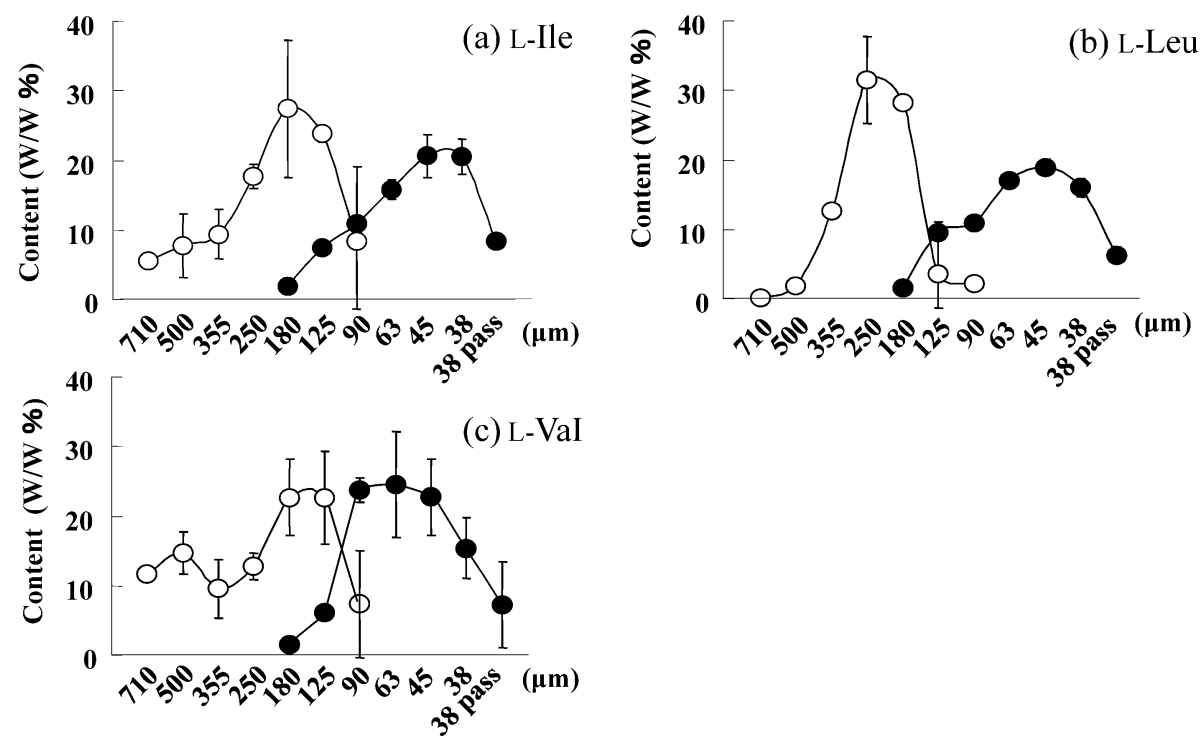
lations of Aminoleban $_{\mathbb{B}}$ EN

(A) $25{ }^{\circ} \mathrm{C}$

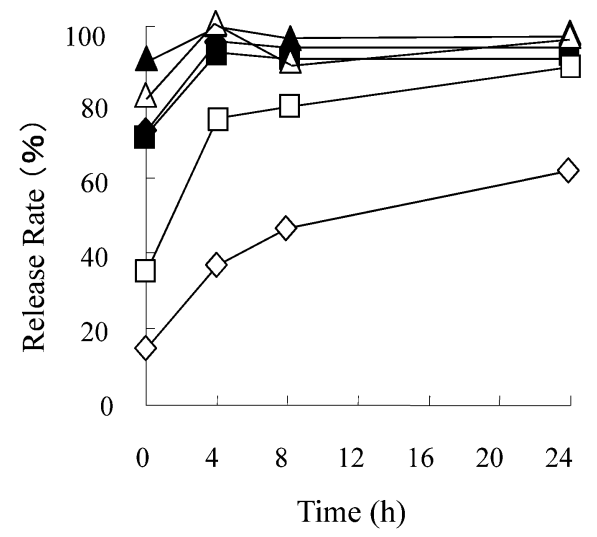

(B) $4{ }^{\circ} \mathrm{C}$

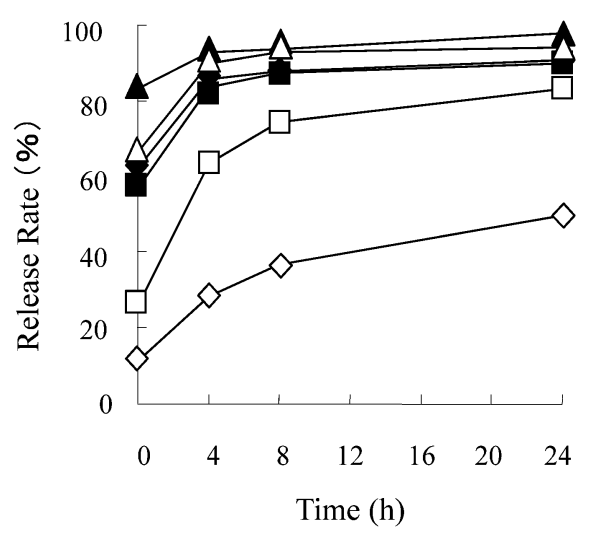

Fig. 5. The Release Characteristics of Each BCAA from Old and Improved Aminoleban $_{\mathbb{E}} \mathrm{EN}$ at $25^{\circ} \mathrm{C}(\mathrm{A})$ and $4^{\circ} \mathrm{C}(\mathrm{B})$ $\square$, improved L-Ile; $\diamond$, improved L-Leu, $\triangle$, improved L-Val, $\mathbf{\square}$, old L-Ile, $\diamond$, old L-Leu, $\boldsymbol{\Delta}$, old, L-Val.

EN 懸濁試料は冷所保存される場合もあるが，温度 の差にかかわらず BCAA 粒子径の大きな製剤から の BCAA の溶出率は BCAA 粒子径の小さな製剤か らの溶出速度に比較して明らかに低く, 服用時の苦 味も抑制することが示唆された。

5. K（カリウム）イオンを含む注射剤のワン ショット静注不可となるよう工夫したキット製剤

Kイオンを含む注射剂が希釈されずにワンショッ ト静注された場合, 患者に重篤な不整脈を起こす危 険性がある。近年医療従事者の利便性と現場での効 率化のためキット製剂となっている。このために希 釈せずにワンショット静注がなされた事例が報告さ
れている. ${ }^{12)}$ 利便性を求めたキット製剤でこのよう なリスクがでてしまうのも本末転倒な事例の気がす るが，便利さゆえの事故を想定した対処法が望まれ る.

このような危険性を防ぐために，キット製剤の注 射筒の先端部分を専用針のみに装着可能にし，輸液 ラインの三方活栓や他の注射針との物理的な接合が できないような構造にした事例がある。しかも専用 の注射針の薬液注入孔が針先でないため, 輸液バッ ク以外には薬液が入らない構造となっている（Fig. 6). ${ }^{12)}$ 


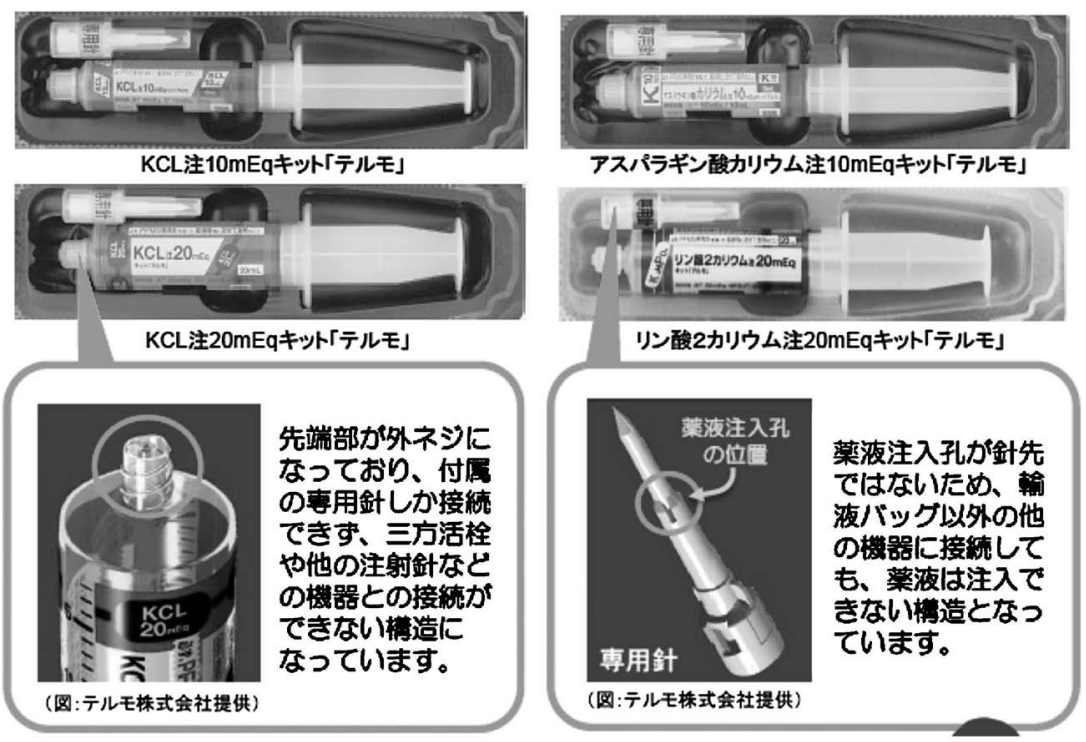

Fig. 6. Dissolving Trade-off by Development of Syringe Type Kit Pharmaceutical Preparation

6. 新生児 · 小児用の薬剤について

内服薬の場合は薬剤の水剂化，薬剤の可溶化のた めに添加剤が使用される．Whittaker らは，喘息の 標準治療として使用されているステロイドの吸入薬 であるデキサメタゾンを早期産児（生後 26 週から 39 週）に投与すると, 可溶化剂として添加されて いるエタノールが，成人 1 週間当たりの許容量より 多く早期産児に摂取される危険性が生じるデー夕を 示している. ${ }^{13)}$ 論文では特に入院で加療を受けた小 児患者のデータを示している.

このような早期産児を含めた新生児や小児に関す る医薬品添加剂の一定期間以上の曝露の安全性・毒 性の問題に触れた論文が少ないが，今後課題になる と思われる。

\section{最後に}

剤形開発の過程で各種のトレードオフがある。そ れを常日頃から意識づけ，それを解決する選択肢を 準備しておくことが重要ではないか。患者視点と開 発の両視点から製剂設計した医薬品開発が望まれる.

利益相反＼cjkstart開示すべき利益相反はない.

\section{REFERENCES}

1) Masuda Y., PHARM TECH JAPAN, 22, 401-412 (2006).

2) Uchida T., Tokuyama E., Yoshida M., J. New Rem. \& Clin., 58, 854-862 (2009).
3) Yoshida T., Tasaki H., Maeda A., Katsuma M., Sako K., Uchida T., J. Control. Release, 131, 47-53 (2008).

4) Shibasaki M., Akaike A., Hashida M., “Iyakuhin kaihatsu ron," ed. by Sakaeda T., Hara H., Okamura N., Hirokawa Publishing Co., Tokyo, 2010, pp. 105-106.

5) Kawabata Y., Wada K., Nakatani M., Yamada S., Onoue S., Int. J. Pharm., 420, 1-10 (2011).

6) Miller J. M., Beig A., Krieg B. J., Carr R. A., Borchardt T. B., Amidon G. E., Amidon G. L., Dahan A., Mol. Pharm., 8, 1848-1856 (2011).

7) Beig A., Miller J. M., Dahan A., Eur. J. Pharm. Biopharm., 85, 1293-1299 (2013).

8) Miller J. M., Beig A., Carr R. A., Spence J. K., Dahan A., Mol. Pharm., 9, 2009-2016 (2012) .

9) Hazekawa M., Haraguchi T., Mutobe M., Yoshida M., Uchida T., Jpn. J. Med. Pharm. Sci., 69, 929-938 (2013).

10) Taiho Pharmaceutical Co., Ltd., Abraxane ${ }_{\mathbb{R}}$ i.v. infusion $100 \mathrm{mg}$, Interview Form, June 2014.

11) Miyanaga Y., Mukai J., Mukai T., Odomi M., Uchida T., Chem. Pharm. Bull., 52, 490-493 (2004).

12) Pharmaceuticals and Medical Devices Agency (PMDA), Medical Safety Information, No. 
19, September 2010.

13) Whittaker A., Currie A. E., Turner M. A., Field D. J., Mulla H., Pandya H. C., Arch.
Dis. Child Fetal Neonatal, 94, F236-F240 (2009). 